\title{
POLA KONSUMSI, ELASTISITAS PENDAPATAN, SERTA VARIABEL-VARIABEL SOSIAL EKONOMI YANG MEMENGARUHI PENGELUARAN KONSUMSI RUMAH TANGGA
}

\author{
Studi Kasus di Provinsi Bengkulu Tahun 2018
}

\author{
(Consumption Pattern Consumption Patterns, Income Elasticities, and Socio-Economic \\ Variables that Influence Household Consumption Expenditure : Case Study in Bengkulu \\ Province on 2018)
}

\author{
Chaterina Dwi Puspita' ${ }^{1}$ Neli Agustina² \\ Politeknik Statistika STIS ${ }^{1}$ \\ Politeknik Statistika STIS 2 \\ Jalan Otto Iskandardinata Nomor 64C, Jakarta- 13330 \\ E-mail: 15.8546@stis.ac.id ${ }^{1}$, neli@stis.ac.id ${ }^{2}$
}

\begin{abstract}
ABSTRAK
Pengeluaran konsumsi rumah tangga merupakan indikator utama kesejahteraan rumah tangga. Pengeluaran konsumsi rumah tangga memiliki share terbesar terhadap Produk Domestik Regional Bruto (PDRB) di Provinsi Bengkulu, yaitu 64,80 persen pada tahun 2017. Selain itu, rata-rata laju pertumbuhan Produk Domestik Regional Bruto (PDRB) Provinsi Bengkulu (5,63 persen) lebih tinggi dari pada rata-rata laju pertumbuhan Produk Domestik Bruto (PDB) nasional (5,27 persen) pada tahun 2012-2017. Namun, pembangunan ekonomi yang baik di Provinsi Bengkulu tidak diikuti dengan rendahnya angka kemiskinan yang dapat menggambarkan kesejahteraan rumah tangga di provinsi tersebut. Angka kemiskinan Provinsi Bengkulu berada di atas angka kemiskinan nasional pada tahun 2012-2017. Penelitian ini bertujuan untuk menganalisis gambaran umum pola konsumsi dan kesejahteraan di Provinsi Bengkulu serta pengaruh perubahan pendapatan (elastisitas pendapatan) dan karakteristik rumah tangga terhadap pola konsumsi makanan dan bukan makanan. Analisis data dilakukan dengan menggunakan Fungsi Engel Kuadratik dan metode regresi berganda dengan estimasi Robust. Hasil penelitian menunjukkan tingginya angka kemiskinan di Provinsi Bengkulu sejalan dengan pola konsumsi untuk rumah tangga, baik miskin maupun tidak miskin, yang masih memiliki rata-rata proporsi pengeluaran konsumsi untuk makanan lebih besar daripada bukan makanan. Pengeluaran konsumsi rumah tangga di perdesaan lebih responsif terhadap perubahan pendapatan rumah tangga serta pendapatan dan karakteristik rumah tangga signifikan terhadap proporsi pengeluaran konsumsi untuk beberapa komoditas makanan dan bukan makanan.
\end{abstract}

Kata kunci: konsumsi rumah tangga, elastisitas pendapatan, regresi robust

\begin{abstract}
Household consumption expenditure is a leading indicator of household welfare. Household consumption expenditure has the largest share of Gross Domestic Regional Product (GDRP) in Bengkulu $(64,80$ percent in 2017). In addition, the average Gross Domestic Regional Product (GDRP) growth of Bengkulu (5,63 percent) is higher than the national Gross Domestic Product (GDP) growth (5,27 percent) in 2012-2017. However, good economic development was not followed by low poverty that can reflect household welfare. The poverty rate of Bengkulu was above the national poverty rate in 2012-2017, which is 15,59 percent (Bengkulu) and 10,12 percent (Indonesia) in 2017. Therefore, this study aims to analyze the general description of household consumption pattern and household welfare, the income elasticity, and household characteristics that significant for commodity of food and nonfood consumption pattern. Data analysis was using Quadratic Engel Functions and multiple regression methods with Robust estimation. The result concluded that the high poverty rate in Bengkulu has implications for the consumption pattern for household, both poor and not poor, which has an average proportion of consumption expenditure for food is greater than non-food. Rural household consumption expenditures are more responsive to changes in household income and household income and household characteristics are significant for the proportion of consumption expenditure for some food and non-food commodities.
\end{abstract}

Keywords: household consumption, income elasticities, robust regression 


\section{PENDAHULUAN}

Pengeluaran konsumsi rumah tangga merupakan indikator utama yang dapat menggambarkan kesejahteraan rumah tangga di suatu wilayah atau negara. Kesejahteraan rumah tangga yang diukur dengan konsumsi ini berkaitan dengan bagaimana rumah tangga tersebut memenuhi kebutuhan dasarnya baik makanan maupun bukan makanan. Semakin tinggi proporsi pengeluaran konsumsi untuk bukan makanan, maka semakin baik taraf hidup atau kesejahteraan rumah tangga karena secara teoritis konsumsi makanan memiliki batas maksimal, sedangkan konsumsi bukan makanan tidak memiliki batas maksimal (BPS, 2010).

Salah satu tujuan Sustainable Development Goals (SDGs) adalah menjamin kehidupan yang sehat dan meningkatkan kesejahteraan penduduk di segala usia. Untuk mengetahui tingkat kesejahteraan penduduk, salah satu indikator yang digunakan oleh Badan Pusat Statistik adalah pengeluaran rumah tangga dengan membandingkan antara pengeluaran konsumsi untuk makanan dan bukan makanan. Secara umum, rata-rata pengeluaran konsumsi untuk makanan per kapita sebulan di Indonesia lebih besar dibandingkan pengeluaran konsumsi untuk bukan makanan, yaitu sebesar 50,94 persen untuk makanan. Jika dilihat dari level provinsi, Bengkulu juga memiliki ratarata pengeluaran konsumsi untuk makanan lebih besar dari pada bukan makanan, yaitu sebesar 52,81 persen untuk makanan. Dengan pola konsumsi tersebut, tingkat kesejahteraan di Indonesia maupun di Provinsi Bengkulu masih relatif rendah.

Kesejahteraan rumah tangga yang diukur dengan konsumsi berkaitan dengan status kemiskinan rumah tangga. Secara teoritis, Hukum Engel menyatakan bahwa peningkatan pendapatan per kapita akan menyebabkan penurunan proporsi pengeluaran konsumsi untuk makanan (Kindlerberger, 1989). Sejalan dengan pola konsumsi di Provinsi Bengkulu, angka kemiskinan di Provinsi Bengkulu masih relatif tinggi yang menempati posisi ke-7 tertinggi di Indonesia dan ke-2 di Pulau Sumatera pada tahun 2017. Selain itu, angka kemiskinan di Provinsi Bengkulu berada diatas angka kemiskinan nasional pada tahun 2012-2017. Sementara itu, perekonomian di Provinsi Bengkulu sudah cukup baik yang dapat dilihat dari rata-rata laju pertumbuhan Produk Domestik Regional Bruto (PDRB) Provinsi Bengkulu (5,63 persen) lebih tinggi dari pada rata-rata laju pertumbuhan Produk Domestik Bruto (PDB) nasional (5,27 persen) pada tahun 2012-2017. Jika dilihat dari share PDRB Provinsi Bengkulu, pengeluaran konsumsi rumah tangga memiliki share terbesar terhadap Produk Domestik Regional Bruto (PDRB) di Provinsi Bengkulu, yaitu 64,80 persen pada tahun 2017. Namun, pembangunan ekonomi yang baik di Provinsi Bengkulu tidak diikuti dengan rendahnya angka kemiskinan yang dapat menggambarkan kesejahteraan rumah tangga di provinsi tersebut.

Permasalahan kemiskinan berkaitan erat dengan kesejahteraan rumah tangga dalam memenuhi kebutuhan dasar hidup, baik pemenuhan kebutuhan dasar makanan maupun bukan makanan. Pola konsumsi rumah tangga menjadi aspek dasar dalam mengukur kesejahteraan rumah tangga sehingga status kemiskinan rumah tangga yang menjadi salah satu ukuran yang mencerminkan tingkat konsumsi rumah tangga dapat menggambarkan kesejahteraan rumah tangga tersebut. Data konsumsi menjadi data pokok dalam perhitungan penduduk miskin yang digunakan untuk melihat seberapa jauh pembangunan ekonomi yang dilakukan dapat meningkatkan kesejahteraan masyarakat (BPS, 2010). Berdasarkan hal tersebut, penelitian ini bertujuan untuk menganalisis pola konsumsi rumah tangga dengan melihat gambaran umum, elastisitas pendapatan dari beberapa komoditas, serta variabel-variabel sosial ekonomi yang memengaruhi pengeluaran konsumsi rumah tangga sehingga hasilnya dapat digunakan untuk menunjang peningkatan kesejahteraan penduduk di Provinsi Bengkulu.

Ada beberapa penelitian terdahulu yang relevan dengan penelitian ini, seperti penelitian yang dilakukan oleh Kahar (2010). Penelitian tersebut menjelaskan bahwa ada perbedaan pola konsumsi rumah tangga antara di perkotaan dan di perdesaan. Hal tersebut disebabkan adanya perbedaan harga makanan dan bukan makanan serta karakteristik wilayah di kedua wilayah tersebut. Secara teori ekonomi, masyarakat perdesaan masih mengutamakan konsumsi makanan dibandingkan dengan bukan makanan, sedangkan masyarakat perkotaan cenderung lebih besar mengalokasikan pendapatannya untuk kebutuhan bukan makanan, seperti sektor pendidikan dan kesehatan (Kahar, 2010). Selain itu, hasil penelitian yang dilakukan oleh Ritonga (1994) menunjukkan bahwa perilaku konsumsi yang dijadikan sebagai indikator tingkat kesejahteraan rumah tangga dapat dipengaruhi 
oleh karakteristik sosial ekonomi rumah tangga, seperti ukuran rumah tangga berdasarkan kelompok umur, usia dan tingkat pendidikan kepala rumah tangga, status kepemilikan rumah, tipe rumah tangga (childless couples, single person, dan single parent), dan sektor lapangan usaha pendapatan utama rumah tangga. Dengan demikian, perubahan karakteristik rumah tangga akan berimplikasi pada perubahan pola konsumsi rumah tangga baik konsumsi untuk makanan maupun bukan makanan. Dari data konsumsi, analisis elastisitas pendapatan dapat dilakukan untuk melihat pengaruh perubahan pendapatan terhadap pengeluaran konsumsi untuk suatu komoditas, seperti penelitian yang dilakukan oleh Yusof dan Duasa (2010). Penelitian tersebut menggunakan Fungsi Engel Kuadratik sebagai pendekatan dari model Almost Ideal Demand System (AIDS) untuk mengestimasi nilai elastisitas pendapatan dan regresi berganda untuk analisis faktor sosial dan demografi yang memengaruhi pola konsumsi untuk setiap komoditas. Berdasarkan uraian permasalahan serta beberapa penelitian terkait, tujuan penelitian ini, antara lain: (1) Mengetahui gambaran umum pola pengeluaran konsumsi untuk makanan dan bukan makanan dan kesejahteraan rumah tangga di Provinsi Bengkulu pada tahun 2018; (2) Menganalisis elastisitas pendapatan dari beberapa komoditas makanan dan bukan makanan; (3) Menganalisis pengaruh karakteristik rumah tangga terhadap pengeluaran konsumsi untuk setiap komoditas makanan dan bukan makanan di Provinsi Bengkulu pada tahun 2018.

\section{METODE}

\section{Landasan Teori}

\section{Teori Hukum Engel}

Hukum Engel menyatakan bahwa seiring meningkatnya pendapatan, persentase pengeluaran konsumsi untuk komoditas makanan akan berkurang dengan asumsi tingkat harga konstan. Teori ini pertama kali dikemukakan oleh seorang ekonom dan statistisi Jerman, Ernst Engel (1821-1896). Engel menetapkan hukum yang menjelaskan bahwa peningkatan pendapatan menyebabkan pengeluaran konsumsi untuk makanan akan meningkat secara aritmatik dan pengeluaran lainnya yang bersifat konsumtif, selain pakaian, sewa, dan bahan bakar akan meningkat secara geometrik (Zimmerman, 1932). Dengan demikian, rumah tangga yang berpendapatan tinggi memiliki persentase pengeluaran konsumsi untuk makanan lebih kecil dibandingkan rumah tangga yang berpendapatan rendah (Deaton dan Muellbauer, 1980). Berdasarkan hal tersebut, Hukum Engel ini juga menyatakan bahwa proporsi pengeluaran konsumsi untuk makanan dapat dijadikan ukuran standar hidup yang baik sehingga dapat mencerminkan tingkat kesejahteraan.

\section{Fungsi Engel}

Fungsi Engel merupakan salah satu fungsi konsumsi yang dapat menggambarkan hubungan antara permintaan konsumsi rumah tangga dan tingkat pendapatan rumah tangga. Fungsi Engel ini biasanya menggunakan data pengeluaran sebagai pendekatan pendapatan (Wan, 1996). Dalam penelitiannya yang bertujuan untuk menghitung elastisitas pendapatan suatu komoditas dengan Fungsi Engel, Wan (1996) menjelaskan bahwa ada dua bentuk Fungsi Engel, yaitu Fungsi Engel dengan dua parameter dan tiga parameter dengan menggunakan proporsi pengeluaran komoditas $k$ terhadap total pengeluaran dari rumah tangga ke- $i\left(\mathrm{~W}_{\mathrm{ik}}\right)$ dan total pengeluaran per kapita rumah tangga ke- $i$ dalam bentuk logaritma $\left(\ln \left[\mathrm{M}_{\mathrm{i}}\right]\right)$, yang masing-masing dapat dituliskan sebagai berikut.

$$
\begin{aligned}
& W_{i k}=a_{0 k}+a_{1 k} \ln \left(M_{i}\right) \ldots \ldots \ldots \ldots \ldots \ldots \ldots \ldots \ldots \ldots \ldots \ldots \\
& W_{i k}=a_{0 k}+a_{1 k} \ln \left(M_{i}\right)+a_{2 k}\left[\ln \left(M_{i}\right)\right]^{2}
\end{aligned}
$$

Fungsi Engel dengan dua parameter atau Fungsi Engel Linier disebut dengan Model WorkingLeser. Model ini hanya dapat menjelaskan perubahan kategori barang suatu komoditas, seperti barang pokok atau barang mewah, yang disebabkan adanya perubahan tingkat pendapatan. Sementara itu, Fungsi Engel dengan tiga parameter ini, yang disebut dengan Fungsi Engel Kuadratik, tidak hanya dapat menjelaskan perubahan kategori barang suatu komoditas yang disebabkan adanya perubahan tingkat pendapatan, tetapi juga dapat menjelaskan preferensi konsumen dalam memenuhi kebutuhannya pada tingkat pendapatan tertentu. 
Berdasarkan Fungsi Engel pada persamaan (1) dan (2), fungsi elastisitas permintaan terhadap pendapatan dari suatu komoditas $\left(E_{k}\right)$ dapat dituliskan sebagai berikut untuk setiap bentuk Fungsi Engel.

$$
\begin{aligned}
& E_{k}=1+a_{1 k} / W_{i k} \ldots \ldots \ldots \ldots \ldots \ldots \ldots \ldots \ldots \ldots \ldots \ldots \\
& E_{k}=1+a_{1 k} / W_{i k}+\left[2 a_{2 k} \ln \left(M_{i}\right)\right] / W_{i k}
\end{aligned}
$$

Berdasarkan nilai elastisitas dari kedua bentuk Fungsi Engel, suatu komoditas dapat berubah dari barang kebutuhan pokok menjadi barang mewah atau sebaliknya sesuai dengan tingkat pendapatannya. Ketika pendapatan meningkat, nilai elastisitas pendapatan untuk komoditas barang pokok dapat menurun dan komoditas barang mewah akan mendekati nilai satu (unity). Sebaliknya, ketika pendapatan menurun, nilai elastisitas pendapatan suatu komoditas dapat meningkat sehingga suatu komoditas akan menjadi bersifat lebih elastis.

\section{Metode Pengumpulan Data}

Penelitian ini mencakup rumah tangga di Provinsi Bengkulu yang menjadi sampel pada Praktik Kerja Lapangan (PKL) Politeknik Statistika STIS Tahun Akademik 2017/2018. Jumlah sampel rumah tangga yang digunakan dalam penelitian ini sebanyak 6570 rumah tangga. Sampel rumah tangga tersebut akan digunakan untuk menganalisis pola pengeluaran konsumsi rumah tangga yang dapat mencerminkan tingkat kesejahteraan rumah tangga dan hubungan pengeluaran konsumsi untuk komoditas makanan dan bukan makanan dengan faktor-faktor yang dapat memengaruhinya. Adapun komoditas makanan dan bukan makanan yang digunakan dalam penelitian ini adalah padipadian; sayur-sayuran; rokok dan tembakau; ikan/udang/cumi/kerang; makanan dan minuman jadi; sewa dan perbaikan rumah; rekening listrik dan bahan bakar; transportasi; biaya pendidikan; barang tahan lama; telekomunikasi; biaya kesehatan.

Penelitian ini menggunakan data sekunder yang diperoleh dari beberapa sumber. Sumber data pendukung diperoleh dari Badan Pusat Statistik (BPS) dan sumber data analisis diperoleh dari hasil Praktik Kerja Lapangan (PKL) Politeknik Statistika STIS Tahun Akademik 2017/2018.

Adapun variabel yang digunakan dalam penelitian ini meliputi variabel dependen dan variabel independen. Variabel dependen yang digunakan adalah proporsi pengeluaran konsumsi makanan dan bukan makanan rumah tangga untuk setiap komoditas terhadap total pengeluaran per bulan. Sementara itu, variabel independen yang digunakan adalah pendapatan rumah tangga per bulan (yang didekati dengen total pengeluaran) serta karakteristik rumah tangga yang terdiri dari jumlah anggota rumah tangga, tingkat pendidikan kepala rumah tangga, lapangan usaha utama rumah tangga, status kemiskinan rumah tangga, dan klasifikasi wilayah tempat tinggal rumah tangga.

\section{Metode Analisis}

Metode analisis yang digunakan dalam penelitian ini adalah analisis deskriptif dan analisis inferensia. Analisis deskriptif bertujuan untuk mengetahui gambaran umum tentang pola pengeluaran konsumsi untuk makanan dan bukan makanan rumah tangga yang dapat menggambarkan kesejahteraan rumah tangga di Provinsi Bengkulu pada tahun 2018. Analisis deskriptif tersebut dilakukan dengan menyajikan tabel, grafik, dan peta tematik. Sementara itu, analisis inferensia bertujuan untuk menganalisis elastisitas pendapatan dari beberapa komoditas makanan dan bukan makanan dengan Fungsi Engel Kuadratik serta menganalisis pengaruh karakteristik rumah tangga terhadap pengeluaran konsumsi untuk setiap komoditas makanan dan bukan makanan di Provinsi Bengkulu pada tahun 2018 dengan menggunakan regresi robust.

\section{Analisis Elastisitas Pendapatan}

Analisis elastisitas pendapatan pada penelitian ini menggunakan Fungsi Engel Kuadratik dengan metode estimasi OLS yang persamaannya dapat dituliskan sebagai berikut.

$$
W_{i k}=a_{0 k}+a_{1 k} \ln (\text { income })_{i}+a_{2 k}\left[\ln \left(\text { income }_{i}\right)\right]^{2}+v_{i k}
$$

Keterangan :

$\mathrm{W}_{\mathrm{ik}} \quad=$ rasio pengeluaran konsumsi untuk komoditas $k$ terhadap total pengeluaran per 
$\begin{aligned} & \text { bulan dari rumah tangga ke- } i \\ \text { In(income })_{i} \quad= & \text { pendapatan rumah tangga ke- } i\end{aligned}$

Berdasarkan persamaan (5), nilai elastisitas permintaan terhadap pendapatan dari suatu komoditas $\left(E_{k}\right)$ dapat diperoleh dari perhitungan sebagai berikut.

$$
E_{k}=1+\frac{\widehat{\alpha_{1 k}}}{\overline{W_{k}}}+\frac{2 \widehat{\alpha_{2 k}} \ln (\overline{\text { income }})}{\overline{W_{k}}}
$$

Analisis Regresi Robust

Analisis regresi robust pada penelitian ini digunakan untuk menganalisis pengaruh karakteristik rumah tangga terhadap pengeluaran konsumsi untuk setiap komoditas makanan dan bukan makanan dengan persamaan sebagai berikut.

$$
W_{i k}=\beta_{0 k}+\beta_{1 k} \ln \left(\text { income }_{i}+\beta_{2 k} \text { size }_{i}+\beta_{3 k} \text { edu } i+\beta_{4 k} \text { sector }_{i}+\beta_{5 k} \text { poorstat }_{i}+\beta_{6 k} \text { locality }_{i}+\varepsilon_{i k}(7)\right.
$$

Keterangan :

$W_{i k} \quad=$ rasio pengeluaran konsumsi untuk komoditas $k$ terhadap total pengeluaran per bulan dari rumah tangga ke-i

income $_{i}=$ pendapatan (pengeluaran) per bulan pada rumah tangga ke- $i$

size $_{i} \quad=$ jumlah anggota rumah tangga pada rumah tangga ke- $i$

$e d u_{i} \quad=$ ijazah/STTB tertinggi kepala rumah tangga ke- $i$ yang berbentuk variabel dummy ( 1 = minimal SMA sederajat ke atas; $0=$ di bawah SMA sederajat)

sector $_{i}=$ lapangan usaha utama rumah tangga ke-iyang berbentuk variabel dummy ( $1=$ nonpertanian; 0 = pertanian)

poorstat $_{i}=$ status kemiskinan rumah tangga ke- $i$ yang berbentuk variabel dummy ( 1 = miskin; 0 = tidak miskin)

locality $_{i}=$ klasifikasi wilayah tempat tinggal rumah tangga ke-iyang berbentuk variabel dummy ( 1 = perkotaan; $0=$ perdesaan $)$

Adapun tahapan analisis regresi robust dapat dilakukan sebagai berikut.

1. Melakukan estimasi koefisien regresi pada data dengan menggunakan metode kuadrat terkecil (OLS).

2. Melakukan uji asumsi klasik pada model regresi OLS.

3. Mendeteksi adanya pencilan (outlier) pada data.

4. Melakukan estimasi koefisien regresi robust dengan menggunakan estimasi-M.

a. Menghitung $\widehat{\boldsymbol{\beta}}^{\mathbf{0}}$ dengan metode kuadrat terkecil.

b. Menghitung nilai pembobot $\operatorname{Huber}\left(w_{H}\right)$ berdasarkan residual yang dihasilkan $\left(e_{i}\right)$.

dengan

$$
w_{H}= \begin{cases}1 & \text { if }\left|u_{i}\right| \leq 1,345 \\ \frac{1,345}{\left|u_{i}\right|} & \text { if }\left|u_{i}\right|>1,345\end{cases}
$$

$$
u_{i}=\frac{e_{i}}{s}=\frac{\left(y_{i}-\widehat{y}_{l}\right)}{\frac{\text { median } \mid e_{i}-\text { median }\left(e_{i}\right) \mid}{0,6745}}
$$

c. Menghitung $\widehat{\boldsymbol{\beta}}^{M}$ dengan metode Weighted Least Square (WLS) dengan menggunakan pembobot $w_{H}$.

d. Mengulangi langkah (b) dan (c) sampai diperoleh nilai $\widehat{\boldsymbol{\beta}}^{\boldsymbol{M}}$ yang konvergen.

e. Melakukan uji signifikansi pada estimasi koefisien regresi yang diperoleh dan uji kebaikan model dengan menghitung nilai $R^{2}$. 


\section{HASIL DAN PEMBAHASAN}

\section{Gambaran Umum Pengeluaran Konsumsi dan Kesejahteraan Rumah Tangga}

Pengeluaran konsumsi rumah tangga merupakan indikator utama yang dapat menggambarkan tingkat kesejahteraan rumah tangga. Tingkat kesejahteraan rumah tangga di Provinsi Bengkulu pada tahun 2018 masih tergolong rendah. Hal tersebut dapat dilihat dari proporsi pengeluaran konsumsi untuk makanan dan bukan makanan rumah tangga di Provinsi Bengkulu. Rumah tangga di Provinsi Bengkulu memiliki rata-rata persentase pengeluaran konsumsi untuk makanan yang lebih besar dari pada bukan makanan, yaitu sebesar 55,24 persen untuk makanan. Jika dilihat dari level kabupaten/kota, seluruh wilayah kabupaten di Provinsi Bengkulu memiliki rata-rata persentase pengeluaran konsumsi untuk makanan yang lebih besar dari pada bukan makanan, sedangkan Kota Bengkulu memiliki rata-rata persentase pengeluaran konsumsi untuk bukan makanan yang lebih besar dari pada makanan, yaitu sebesar 47,06 persen untuk makanan.

Berdasarkan hukum Engel, semakin tinggi pendapatan yang menunjukkan tingkat kesejahteraan yang lebih baik, proporsi pengeluaran konsumsi untuk makanan akan berkurang. Pada Gambar 1, seluruh kabupaten di Provinsi Bengkulu memiliki tingkat pengeluaran yang tergolong sedang dan rendah serta Kota Bengkulu memiliki tingkat pengeluaran yang tergolong tinggi. Sejalan dengan hukum Engel, Kota Bengkulu yang tergolong tinggi tingkat pengeluarannya sebagai proksi tingkat pendapatan memiliki proporsi pengeluaran konsumsi makanan yang lebih rendah dari pada bukan makanan, sedangkan wilayah kabupaten yang masih relatif rendah tingkat pengeluarannya memiliki proporsi pengeluaran konsumsi makanan yang lebih tinggi.

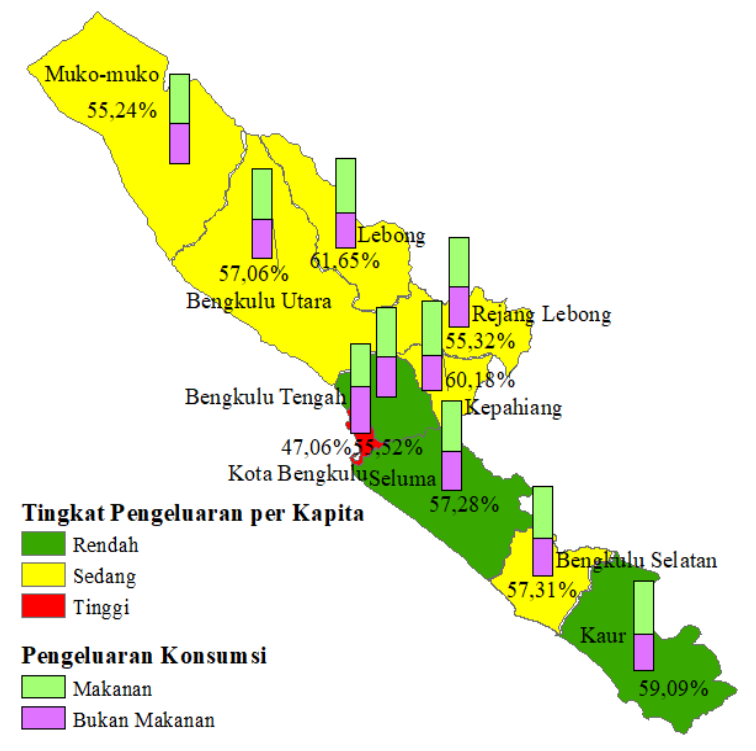

Sumber : PKL Politeknik Statistika STIS 2018, data diolah

Gambar 1. Peta Persebaran Tingkat Pengeluaran Konsumsi dan Persentase Pengeluaran Konsumsi Makanan dan Nonmakanan per Kapita Sebulan Rumah Tangga di Provinsi Bengkulu Tahun 2018

Berdasarkan Tabel 1, ada perbedaan rata-rata persentase pengeluaran konsumsi untuk makanan dan bukan makanan menurut karakteristik rumah tangga di Provinsi Bengkulu. Tingginya angka kemiskinan di Provinsi Bengkulu sejalan dengan pola konsumsi rumah tangga di provinsi tersebut, yaitu baik rumah tangga miskin maupun tidak miskin memiliki rata-rata proporsi pengeluaran konsumsi untuk makanan yang lebih besar dari pada rata-rata proporsi pengeluaran konsumsi untuk bukan makanan. Hal tersebut mengindikasikan bahwa kesejahteraan rumah tangga di Provinsi Bengkulu masih relatif rendah. Selain itu, rumah tangga di perkotaan lebih sejahtera dibandingkan rumah tangga di perdesaan. Rumah tangga di daerah perdesaan Provinsi Bengkulu masih cenderung mengeluarkan sebagian besar pendapatannya untuk makanan dengan proporsi pengeluaran konsumsi untuk makanan sebesar 58,08 persen. 
Banyaknya rumah tangga yang memiliki mata pencaharian di sektor pertanian dan sebagian besarnya tergolong rumah tangga miskin menyebabkan kesejahteraan rumah tangga di Provinsi Bengkulu relatif rendah. Rumah tangga pertanian cenderung membelanjakan pendapatannya untuk konsumsi makanan dengan rata-rata persentase pengeluaran konsumsi untuk makanan sebesar 54,86 persen. Sementara itu, pemenuhan kebutuhan makanan rumah tangga nonpertanian sudah dapat terpenuhi dengan baik sehingga rumah tangga nonpertanian dapat mengalokasikan sebagian besar pendapatannya untuk keperluan bukan makanan dengan proporsi sebesar 54,65 persen.

Tabel 1. Rata-rata Persentase Pengeluaran Konsumsi Makanan dan Nonmakanan per Kapita Sebulan Rumah Tangga Menurut Karakteristik Rumah Tangga di Provinsi Bengkulu Tahun 2018

\begin{tabular}{|c|c|c|c|}
\hline $\begin{array}{c}\text { Karakteristik Rumah } \\
\text { Tangga }\end{array}$ & Kategori & $\begin{array}{l}\text { Makanan } \\
(\%)\end{array}$ & $\begin{array}{c}\text { Nonmakanan } \\
(\%)\end{array}$ \\
\hline$(1)$ & $(2)$ & (3) & (4) \\
\hline \multirow{2}{*}{ Status Kemiskinan } & Miskin & 62,92 & 37,08 \\
\hline & Tidak Miskin & 54,12 & 45,88 \\
\hline \multirow{2}{*}{ Klasifikasi Wilayah } & Perdesaan & 58,08 & 41,92 \\
\hline & Perkotaan & 48,58 & 51,42 \\
\hline \multirow{2}{*}{ Lapangan Usaha Utama } & Pertanian & 54,86 & 45,14 \\
\hline & Nonpertanian & 45,35 & 54,65 \\
\hline Jumlah Anggota Rumah & 1-4 orang & 48,55 & 51,45 \\
\hline Tangga & $>4$ orang & 50,21 & 49,79 \\
\hline Tingkat Pendidikan Kepala & $<$ SMA & 55,26 & 44,74 \\
\hline Rumah Tangga & $>=$ SMA & 43,38 & 56,62 \\
\hline
\end{tabular}

Sumber : PKL Politeknik Statistika STIS 2018, data diolah

Kesejahteraan rumah tangga yang rendah di Provinsi Bengkulu implikasi dari kondisi rumah tangga di Provinsi Bengkulu yang sebagian besar kepala rumah tangganya masih berpendidikan rendah. Rumah tangga dengan kepala rumah tangga berpendidikan minimal SMA cenderung membelanjakan pendapatannya untuk konsumsi bukan makanan dengan rata-rata persentase pengeluaran konsumsi untuk bukan makanan sebesar 56,62 persen. Sementara itu, rumah tangga dengan kepala rumah tangga berpendidikan kurang dari SMA memiliki rata-rata persentase pengeluaran konsumsi untuk makanan lebih besar daripada konsumsi untuk bukan makanan, yaitu sebesar 55,26 persen untuk makanan.

\section{Elastisitas Pendapatan}

Hasil analisis elastisitas pendapatan untuk beberapa komoditas makanan dan bukan makanan di Provinsi Bengkulu Tahun 2018 dapat dilihat pada Tabel 2. Secara umum, nilai elastisitas pendapatan untuk semua komoditas makanan dan bukan makanan lebih besar dari nol, artinya komoditas tersebut merupakan barang normal yang jika terjadi peningkatan pendapatan rumah tangga, proporsi pengeluaran konsumsi untuk komoditas tersebut akan bertambah.

Dilihat dari komoditas makanan, sebagian besar komoditas makanan memiliki nilai elastisitas pendapatan kurang dari satu, kecuali komoditas makanan dan minuman jadi. Hal tersebut menyimpulkan bahwa sebagian besar komoditas makanan merupakan barang pokok dan hanya komoditas makanan dan minuman jadi yang dikategorikan sebagai barang mewah. Namun, makanan dan minuman jadi di daerah perkotaan masih menjadi barang pokok, artinya rumah tangga di daerah perkotaan cenderung lebih banyak mengonsumsi makanan dan minuman jadi dibandingkan rumah tangga di daerah perdesaan. Sementara itu, sebagian besar komoditas bukan makanan merupakan barang mewah karena memiliki nilai elastisitas lebih dari satu. Dari keseluruhan komoditas, padi-padian merupakan komoditas yang paling inelastis, artinya perubahan pendapatan tidak berpengaruh banyak terhadap proporsi padi-padian yang dikonsumsi rumah tangga.

Menurut tipe wilayah, nilai elastisitas pendapatan di daerah perdesaan lebih elastis dibandingkan di daerah perkotaan. Artinya, perubahan proporsi pengeluaran konsumsi yang dikonsumsi rumah tangga di daerah perdesaan lebih responsif terhadap perubahan pendapatan rumah tangganya. Kondisi tersebut mendukung fakta bahwa rumah tangga di daerah perkotaan memiliki tingkat 
pendapatan yang lebih baik sehingga perubahan pendapatan akan lebih rendah pengaruhnya terhadap perubahan proporsi komoditas yang dikonsumsi oleh rumah tangga. Selain itu, suatu komoditas yang dikonsumsi oleh rumah tangga kemungkinan dapat terjadi perubahan kategori dari barang pokok di perkotaan menjadi barang mewah di perdesaan.

Tabel 2. Elastisitas Pendapatan

\begin{tabular}{lccc}
\hline \multicolumn{1}{c}{ Komoditas } & Total & Perdesaan & Perkotaan \\
\hline \multicolumn{1}{c}{$(1)$} & $(2)$ & $(3)$ & $(4)$ \\
\hline Padi-padian & 0,4614 & 0,5058 & 0,4343 \\
Sayur-sayuran & 0,6468 & 0,6857 & 0,5997 \\
Rokok dan tembakau & 0,9128 & 0,9808 & 0,7732 \\
Ikan/udang/cumi/kerang & 0,9037 & 0,9032 & 0,8950 \\
Makanan dan minuman jadi & 1,2435 & 1,2757 & 0,9701 \\
Sewa dan perbaikan rumah & 0,9479 & 0,8966 & 0,9773 \\
Rekening listrik dan bahan bakar & 0,7868 & 0,7478 & 0,8163 \\
Transportasi & 1,2653 & 1,2999 & 1,2462 \\
Biaya pendidikan & 1,4318 & 1,3589 & 1,2863 \\
Barang tahan lama & 2,5739 & 2,6974 & 2,4962 \\
Telekomunikasi & 1,5334 & 1,5639 & 1,2352 \\
Biaya kesehatan & 1,4475 & 1,4831 & 1,5098 \\
\hline
\end{tabular}

Sumber: PKL Politeknik Statistika STIS 2018, data diolah

Komoditas biaya pendidikan secara umum bersifat elastis dan menjadi barang mewah baik di perkotaan maupun di perdesaan. Meskipun sektor pendidikan masih menjadi barang mewah bagi rumah tangga baik di perkotaan dan perdesaan, hal tersebut menunjukkan bahwa rumah tangga di perkotaan dan di perdesaan sudah memprioritaskan sektor pendidikan sehingga rumah tangga di kedua wilayah tersebut relatif besar merespons sektor pendidikan, jika terjadi peningkatan pendapatan. Begitu juga dengan biaya kesehatan, nilai elastisitas pendapatan terhadap biaya kesehatan lebih besar dari satu, artinya sektor kesehatan masih menjadi barang mewah bagi rumah tangga di perkotaan dan di perdesaan. Namun, komoditas biaya kesehatan di perkotaan bersifat lebih elastis dibandingkan di perdesaan.

\section{Analisis Pengaruh Karakteristik Rumah Tangga terhadap Pengeluaran Konsumsi untuk Komoditas Makanan dan Nonmakanan}

Analisis regresi pada penelitian ini digunakan untuk mengidentifikasi dan menganalisis karakteristik rumah tangga yang signifikan terhadap pengeluaran konsumsi untuk suatu komoditas. Karena adanya pencilan dan amatan berpengaruh, metode OLS tidak lagi relevan digunakan untuk analisis regresi. Dengan demikian, analisis regresi pada penelitian ini menggunakan estimasi robust sehingga model regresi yang terbentuk dapat resisten terhadap pencilan dan amatan berpengaruh.

Tabel 3. Hasil Regresi Robust untuk Komoditas Makanan

\begin{tabular}{lrrrrr}
\hline \multicolumn{1}{c}{ Variabel Dependen } & \multicolumn{1}{c}{$\begin{array}{c}\text { Padi- } \\
\text { padian }\end{array}$} & $\begin{array}{c}\text { Sayur- } \\
\text { sayuran }\end{array}$ & $\begin{array}{r}\text { Rokok dan } \\
\text { tembakau }\end{array}$ & $\begin{array}{r}\text { Ikan/udang/ } \\
\text { cumi/kerang }\end{array}$ & $\begin{array}{r}\text { Makanan dan } \\
\text { minuman jadi }\end{array}$ \\
\hline (Konstanta) & 1,0643 & 0,3184 & 0,1173 & 0,1159 & $-0,0863$ \\
Ln(pendapatan) & $-0,0663^{*}$ & $-0,0181^{*}$ & $-0,0036^{*}$ & $-0,0053^{*}$ & $0,0086^{*}$ \\
Jumlah ART & $0,0175^{*}$ & $0,0031^{*}$ & $0,0069^{*}$ & $0,0014^{*}$ & $-0,0008$ \\
Tingkat Pendidikan KRT & $-0,012^{*}$ & $-0,0044^{*}$ & $-0,0163^{*}$ & $0,0053^{*}$ & $0,0065^{*}$ \\
Lapangan usaha utama & $-0,0251^{*}$ & $-0,0052^{*}$ & $-0,0034$ & $-0,0004$ & $0,0113^{*}$ \\
Status kemiskinan & $0,0284^{*}$ & $-0,005^{*}$ & $-0,015^{*}$ & $-0,0091^{*}$ & $-0,0086^{*}$ \\
Klasifikasi wilayah & $-0,0161^{*}$ & $-0,0061^{*}$ & $-0,0079^{*}$ & $-0,0028^{*}$ & $0,0084^{*}$ \\
\hline Uji F & Sign. & Sign. & Sign. & Sign. & Sign. \\
\hline Adj. R & 0,5679 & 0,1726 & 0,0520 & 0,0746 & 0,1973 \\
\hline
\end{tabular}

Keterangan : $*$ signifikan pada $\mathrm{a}=5$ persen

Sumber: PKL Politeknik Statistika STIS 2018, data diolah 
Tabel 4. Hasil Regresi Robust untuk Komoditas Bukan Makanan

\begin{tabular}{|c|c|c|c|c|c|c|c|}
\hline $\begin{array}{l}\text { Variabel } \\
\text { Dependen }\end{array}$ & $\begin{array}{l}\text { Sewa dan } \\
\text { perbaikan } \\
\text { rumah }\end{array}$ & $\begin{array}{l}\text { Rekening } \\
\text { listrik \& } \\
\text { bahan } \\
\text { bakar }\end{array}$ & $\begin{array}{c}\text { Transport } \\
\text { asi }\end{array}$ & $\begin{array}{c}\text { Biaya } \\
\text { pendidikan }\end{array}$ & $\begin{array}{l}\text { Barang } \\
\text { tahan } \\
\text { lama }\end{array}$ & $\begin{array}{l}\text { Telekomu } \\
\text { nikasi }\end{array}$ & $\begin{array}{c}\text { Biaya } \\
\text { kesehatan }\end{array}$ \\
\hline (Konstanta) & 0,5824 & 0,2602 & $-0,0642$ & $-0,0191$ & $-0,0744$ & $-0,0573$ & $-0,0106$ \\
\hline Ln(pendapatan) & $-0,0292 *$ & $-0,0147 *$ & $0,0067 *$ & $0,0012 *$ & $0,0056 *$ & $0,0045^{*}$ & $0,0012 *$ \\
\hline Jumlah ART & $-0,0075^{*}$ & $0,0015^{*}$ & $0,0024 *$ & $0,0036 *$ & $-0,0009 *$ & 0,0002 & $-0,0001$ \\
\hline $\begin{array}{l}\text { Tingkat } \\
\text { Pendidikan KRT }\end{array}$ & 0,0097* & $0,0038^{*}$ & 0,0069* & $0,0021^{*}$ & $0,0008^{*}$ & $0,0059 *$ & $-0,0009 *$ \\
\hline $\begin{array}{l}\text { Lapangan usaha } \\
\text { utama }\end{array}$ & 0,0043* & $0,0034 *$ & $-0,0009$ & 0,0008 & $0,0005^{*}$ & 0,0030* & 0,0002 \\
\hline $\begin{array}{l}\text { Status } \\
\text { kemiskinan }\end{array}$ & $-0,0042$ & $-0,0054 *$ & $-0,0071^{*}$ & $-0,0016$ & $0,0009 *$ & $-0,0019 *$ & $-0,0003$ \\
\hline $\begin{array}{l}\text { Klasifikasi } \\
\text { wilayah }\end{array}$ & $0,0291 *$ & $0,0037 *$ & $-0,0049 *$ & $0,0049 *$ & $-0,0013^{*}$ & $0,0036^{*}$ & $-0,0006 *$ \\
\hline Uji F & Sign. & Sign. & Sign. & Sign. & Sign. & Sign. & Sign. \\
\hline Adj. $\mathbf{R}^{2}$ & 0,1976 & 0,1219 & 0,1329 & 0,4589 & 0,8955 & 0,3509 & 0,8023 \\
\hline
\end{tabular}

Keterangan : * $=$ signifikan pada $\mathrm{a}=5$ persen

Sumber : PKL Politeknik Statistika STIS 2018, data diolah

Analisis regresi robust pada penelitian ini dilakukan dengan metode estimasi-M yang hasilnya dapat dilihat pada Tabel $\mathbf{3}$ (komoditas makanan) dan Tabel 4 (komoditas bukan makanan). Dari hasil analisis regresi, nilai koefisien determinasi $\left(R^{2}\right)$ dari model pada setiap komoditas makanan dan bukan makanan bervariasi. Komoditas barang tahan lama memiliki nilai adjusted $R^{2}$ terbesar, yaitu sebesar 89,55 persen, sedangkan komoditas rokok dan tembakau memiliki nilai adjusted $R^{2}$ terkecil, yaitu sebesar 5,20 persen. Nilai koefisien determinasi tersebut menunjukkan besaran keragaman dari proporsi pengeluaran konsumsi untuk suatu komoditas yang dapat dijelaskan oleh variabel independen yang digunakan pada model.

Berdasarkan nilai estimasi koefisien regresi, pendapatan yang didekatkan dengan total pengeluaran rumah tangga signifikan terhadap proporsi pengeluaran konsumsi untuk setiap komoditas makanan dan bukan makanan. Adanya kebiasan anggota rumah tangga di Provinsi Bengkulu yang cenderung merokok baik pada rumah tangga berpendapatan rendah maupun tinggi menyebabkan besarnya pendapatan tidak berpengaruh besar terhadap pengeluaran konsumsi untuk rokok dan tembakau. Pendapatan rumah tangga memiliki hubungan negatif dan signifikan terhadap proporsi pengeluaran konsumsi untuk komoditas makanan, kecuali komoditas makanan dan minuman jadi. Sebaliknya, koefisien pendapatan bernilai positif dan signifikan untuk sebagian besar komoditas bukan makanan. Hasil tersebut sesuai dengan Hukum Engel yang menyimpulkan bahwa rumah tangga di Provinsi Bengkulu cenderung meningkatkan alokasi pengeluarannya untuk konsumsi bukan makanan ketika terjadi peningkatan pendapatan rumah tangga yang menunjukkan semakin baik kesejahteraan rumah tangga tersebut.

Dilihat dari karakteristik rumah tangga, tingkat pendidikan kepala rumah tangga signifikan terhadap proporsi pengeluaran konsumsi untuk semua komoditas makanan dan bukan makanan. Koefisien tingkat pendidikan kepala rumah tangga bernilai positif dan signifikan untuk komoditas ikan/udang/cumi/kerang, makanan dan minuman jadi, dan sebagian besar komoditas bukan makanan. Hasil tersebut menyimpulkan bahwa semakin tinggi tingkat pendidikan kepala rumah tangga, maka rumah tangga akan cenderung lebih banyak mengalokasikan pendapatannya untuk konsumsi makanan protein hewani, makanan dan minuman jadi, dan konsumsi bukan makanan sehingga dapat disimpulkan kesejahteraan rumah tangga dengan kepala rumah tangga berpendidikan tinggi relatif lebih baik. Selain itu, koefisien dari variabel dummy yang menunjukkan lapangan usaha utama rumah tangga di sektor nonpertanian bernilai negatif untuk komoditas makanan dan bernilai positif untuk komoditas bukan makanan. Rumah tangga dengan lapangan usaha utama di sektor nonpertanian cenderung mengalokasikan lebih pengeluarannya untuk konsumsi bukan makanan yang artinya kesejahteraan rumah tangga nonpertanian lebih baik dari pada rumah tangga pertanian. 
Secara umum, status kemiskinan rumah tangga memiliki hubungan negatif dengan komoditas bukan makanan, artinya hal ini sesuai dengan pernyataan bahwa kesejahteraan rumah tangga miskin relatif lebih rendah dibandingkan rumah tangga tidak miskin. Komoditas pendidikan dan kesehatan yang memiliki estimasi koefisien regresi status kemiskinan yang negatif mengindikasikan bahwa rumah tangga miskin kurang memerhatikan sektor pendidikan dan kesehatan dibandingkan dengan rumah tangga tidak miskin. Sementara itu, klasifikasi wilayah tempat tinggal rumah tangga signifikan terhadap pengeluaran konsumsi untuk sebagian besar komoditas makanan dan bukan makanan. Proporsi pengeluaran konsumsi untuk komoditas makanan, kecuali komoditas makanan dan minuman jadi, lebih besar dikonsumsi oleh rumah tangga di daerah perdesaan dibandingkan rumah tangga di daerah perkotaan.

\section{KESIMPULAN}

Beberapa kesimpulan dari penelitian ini adalah sebagai berikut.

1. Kesejahteraan rumah tangga di Provinsi Bengkulu Tahun 2018 relatif rendah yang ditunjukkan dengan pola konsumsi rumah tangga yang menunjukkan rata-rata proporsi pengeluaran konsumsi untuk makanan lebih besar dibandingkan bukan makanan untuk seluruh kabupaten di Provinsi Bengkulu. Tingginya angka kemiskinan di Provinsi Bengkulu sejalan dengan pola pengeluaran konsumsi rumah tangganya, yaitu baik rumah tangga miskin maupun tidak miskin di Provinsi Bengkulu memiliki rata-rata proporsi pengeluaran konsumsi untuk makanan yang lebih besar daripada rata-rata proporsi pengeluaran konsumsi untuk bukan makanan.

2. Berdasarkan nilai elastisitas pendapatan, sebagian besar komoditas makanan tergolong barang normal, kecuali makanan dan minuman jadi, sedangkan sebagian besar komoditas bukan makanan tergolong barang mewah. Perbedaan tingkat harga dan karakteristik wilayah di perdesaan dan perkotaan berimplikasi terhadap nilai elastisitas pendapatan yang berbeda di kedua wilayah tersebut, yaitu pengeluaran konsumsi rumah tangga di perdesaan lebih responsif terhadap perubahan pendapatan rumah tangga.

3. Hasil analisis regresi menunjukkan bahwa pendapatan dan karakteristik rumah tangga signifikan terhadap proporsi pengeluaran konsumsi untuk beberapa komoditas makanan dan bukan makanan.

\section{DAFTAR PUSTAKA}

Al-Habashneh, Fedel dan Khalid A. (2014). Estimating The Engel Curves for Household Expenditures in Jordan from 2010 to 2011. European Scientific Journal January 2014 Edition, 10(2).

Deaton, A. \& Muellbauer, J. (1980). Economics and Consumer Behavior. Cambridge: Cambridge University Press.

Draper, N. R. dan H. Smith. (1998). Applied Regression Analysis, Third Edition. USA: John Wiley \& Sons, Inc. Gujarati, D. N. (2004). Basic Econometrics, Fourth Edition. New York: The McGraw-Hill Companies.

Kahar, M. (2010). Analisis Pola Konsumsi Daerah Perkotaan dan Perdesaan serta Keterkaitannya dengan Karakteristik Sosial Ekonomi di Propinsi Banten. Tesis Institut Pertanian Bogor. Bogor. $61 \mathrm{hlm}$.

Kindlerberger, C. P. (1989). Economic Laws and Economic History. Cambridge: Cambridge University Press.

Montgomery, D. C., Peck, E. A., dan G. Geoffrey Vining. (2012). Introduction to Linear Regression on Analysis, Fifth Edition. USA: John Wiley \& Sons, Inc.

PKL Politeknik Statistika STIS. (2018). Estimasi Pengeluaran dan Tabungan dengan Small Area Estimation (SAE) di Provinsi Bengkulu Tahun 2018. Laporan PKL Politeknik Statistika STIS. Jakarta.

Ritonga, Hamonangan. (1994). The Impact of Household Characteristics on Household Consumption Behavior: A Demand System Analysis on The Consumption Behavior of Urban Households in The Province of Central Java, Indonesia. Tesis Iowa State University. Iowa. $138 \mathrm{hlm}$.

Wan, Guang H. (1996). Income Elasticities of Household Demand in Rural China (Estimates from Crosssectional Survey Data). Journal of Economic Studies 23(3), 18-33.

Yusof, S. A. \& J. Duasa. (2010). Consumption Patterns and Income Elasticities in Malaysia. Malaysian Journal of Economic Studies, 47(2), 91-106. 